\title{
Pigs fed various levels of crude protein and raised above the thermoneutral zone: effects on protein metabolism and nitrogen balance
}

Suínos alimentados com diferentes níveis de proteína bruta e criados acima da zona termoneutra:

efeitos no metabolismo de proteínas e equilíbrio de nitrogênio

Cerdos alimentados con varios niveles de proteína cruda y criados por encima de la zona

termoneutral: efectos sobre el metabolismo de las proteínas y el equilibrio de nitrógeno

Received: 12/19/2020 | Reviewed: 12/21/2020 | Accept: 01/07/2021 | Published: 01/08/2021

Stela Cássia de Oliveira

ORCID: https://orcid.org/0000-0002-0025-5826 Universidade Estadual do Mato Grosso do Sul, Brasil E-mail: stela.zootecnista@outlook.com

Mayla Regina Souza

ORCID: https://orcid.org/0000-0002-2452-9633

Universidade do Estado de Santa Catarina, Brasil e-mail: souza_mayla@hotmail.com

Rafael Alan Baggio

ORCID: https://orcid.org/0000-0002-6303-6401

Universidade do Estado de Santa Catarina, Brasil Email: rafaelbaggio12@hotmail.com

Jhonatan Pazinato Boito

ORCID: https://orcid.org/0000-0001-8699-6782

Universidade do Estado de Santa Catarina, Brasil Email: jhonatan.zootecnista@gmail.com

Tiago J. Pasquetti

ORCID: https://orcid.org/0000-0001-5157-0458 Universidade Estadual do Mato Grosso do Sul, Brasil E-mail: pasquettizoo@uems.com.br

Tania Mara Batista dos Santos

ORCID: https://orcid.org/0000-0001-9107-5259 Universidade Estadual do Mato Grosso do Sul, Brasil Email: tania@uems.br

Rafael Noal Moresco

ORCID: https://orcid.org/0000-0003-3072-5080 Universidade Federal de Santa Maria, Brasil Email: rnmoresco@ufsm.br

\author{
Aleksandro Schafer Da Silva \\ ORCID: https://orcid.org/0000-0001-5459-3823 \\ Universidade do Estado de Santa Catarina, Brasil \\ Email: aleksandro.silva@udesc.br \\ Diovani Paiano \\ ORCID: https://orcid.org/0000-0003-2715-9524 \\ Universidade do Estado de Santa Catarina, Brasil \\ Email: diovani.paiano@udesc.br
}

\begin{abstract}
We evaluated performance, nutrient balance, nitrogen balance, and serum parameters in pigs in the nursery phase raised in environmental conditions above the thermoneutral zone that were fed with diets containing various levels of crude protein $(\mathrm{CP})$. A total of 15 barrows $(22.75 \pm 1.58 \mathrm{~kg})$ were housed in metabolism pens and distributed in a completely randomized design with three treatments: $15.5 \%, 18.3 \%$, and $21.0 \%$ of $\mathrm{CP}$, designated $\mathrm{T} 15$, T18, and T21, respectively. There was a gradual increase of temperature over the first three days from 25 to $29.1 \pm 2.3{ }^{\circ} \mathrm{C}$. From d18 to $\mathrm{d} 20$ of the experiment, pigs received the same diet $(18 \% \mathrm{CP})$ and thermoneutral conditions were reestablished (22.9 $\pm 1.9^{\circ} \mathrm{C}$ ). There were higher values of urinary, excreted, and absorbed nitrogen in T21, followed by T18 and T15. Blood urea levels were higher in treatments with higher protein levels. On d4 (adaptation period), cholesterol levels were higher in the T15 group than in the T21 group, antioxidant power of iron reduction values were lower in the T18 group than the T21 group. Advanced oxidation protein products (AOPP) on day 16 were higher in the T15 group, associated with the accumulation of heat stress and lower CP diets. Similar results were obtained for T18 with higher AOPP values on $\mathrm{d} 16$ than on $\mathrm{d} 8$ and $\mathrm{d} 12$. However, there were greater AOPP values in the T21 group on $\mathrm{d} 20$ (when the $\mathrm{CP}$ level was reduced to $18 \%$ ) than on $\mathrm{d} 8$. Amino acid supplementation and reduction of $\mathrm{CP}$ in the diet to levels of
\end{abstract}


$15.5 \%$ in piglets raised above the thermoneutral zone improved the use of CP. Furthermore, $15.5 \%$ of CP in the diet reduced the excretion of urinary nitrogen. The N-retention was not affected by dietary CP level, using the ideal protein concept. The use of $21 \%$-CP in the diet efficiently avoided exacerbation of protein oxidation for pigs raised above thermoneutrality.

Keywords: Amino acids; Digestibility; Oxidation protein; Swine; Thermoneutrality; Urea.

\title{
Resumo
}

Avaliamos o desempenho, o balanço de nutrientes, o balanço de nitrogênio e os parâmetros séricos em suínos na fase de creche criados em condições ambientais acima da zona termoneutra, alimentados com dietas contendo diferentes níveis de proteína bruta (PB). Um total de 15 suínos machos castrados $(22,75 \pm 1,58 \mathrm{~kg})$ foram alojados em baias de metabolismo e distribuídos em um delineamento inteiramente casualizado com três tratamentos: $15,5 \%$, 18,3\% e 21,0\% de PB, designados T15, T18 e T21, respectivamente. Houve um aumento gradual da temperatura nos primeiros três dias de 25 para $29,1 \pm 2,3{ }^{\circ} \mathrm{C}$. Do d 18 ao d20 do experimento, os suínos receberam a mesma dieta (18\% PB) e as condições termoneutras foram restabelecidas $\left(22,9 \pm 1,9^{\circ} \mathrm{C}\right)$. Houve maiores valores de nitrogênio urinário, excretado e absorvido em T21, seguido de T18 e T15. Os níveis de uréia no sangue foram maiores nos tratamentos com níveis mais elevados de proteína. No d4 (período de adaptação), os níveis de colesterol foram maiores no grupo T15 do que no grupo T21, o poder antioxidante do valor de redução do ferro foi menor no grupo T18 do que no grupo T21. Os produtos proteicos de oxidação avançada (AOPP) no dia 16 foram maiores no grupo T15, associados ao acúmulo de estresse térmico e dietas com menor PB. Resultados semelhantes foram obtidos para T18 com valores de AOPP mais altos em d16 do que em d8 e d12. No entanto, houve maiores valores de AOPP no grupo T21 no d20 (quando o nível de PB foi reduzido para 18\%) do que no d8. A suplementação de aminoácidos e a redução da PB na dieta para níveis de $15,5 \%$ em leitões criados acima da zona termoneutra melhoraram o uso de PB. Além disso, 15,5\% de PB na dieta reduziu a excreção de nitrogênio urinário. A retenção de $\mathrm{N}$ não foi afetada pelo nível de $\mathrm{PB}$ da dieta, usando o conceito de proteína ideal. O uso de $21 \%$-PB na dieta evitou de forma eficiente a exacerbação da oxidação de proteínas em suínos criados acima da termoneutralidade.

Palavras-chave: Aminoácidos; Digestibilidade; Proteína de oxidação; Suíno; Termoneutralidade; Ureia.

\begin{abstract}
Resumen
Evaluamos el desempeño, balance de nutrientes, balance de nitrógeno y parámetros séricos en cerdos en fase de crianza criados en condiciones ambientales por encima de la zona termoneutra que fueron alimentados con dietas conteniendo varios niveles de proteína cruda (PC). Un total de 15 carretillas $(22,75 \pm 1,58 \mathrm{~kg})$ se alojaron en corrales de metabolismo y se distribuyeron en un diseño completamente al azar con tres tratamientos: $15,5 \%, 18,3 \%$ y $21,0 \%$ de PC, designados T15, T18 y T21, respectivamente. Hubo un aumento gradual de la temperatura durante los primeros tres días de 25 a $29,1 \pm 2,3{ }^{\circ} \mathrm{C}$. Desde el d18 al d20 del experimento, los cerdos recibieron la misma dieta (18\% PC) y se restablecieron las condiciones termoneutras $\left(22,9 \pm 1,9{ }^{\circ} \mathrm{C}\right)$. Hubo valores más altos de nitrógeno urinario, excretado y absorbido en T21, seguido de T18 y T15. Los niveles de urea en sangre fueron más altos en tratamientos con niveles más altos de proteínas. En el d4 (período de adaptación), los niveles de colesterol fueron más altos en el grupo T15 que en el grupo T21, el poder antioxidante de los valores de reducción de hierro fueron más bajos en el grupo T18 que en el grupo T21. Los productos de proteína de oxidación avanzada (AOPP) el día 16 fueron más altos en el grupo T15, asociados con la acumulación de estrés por calor y dietas más bajas de PC. Se obtuvieron resultados similares para T18 con valores de AOPP más altos en d16 que en d8 y d12. Sin embargo, hubo mayores valores de AOPP en el grupo T21 el día 20 (cuando el nivel de PC se redujo al 18\%) que el día 8. La suplementación con aminoácidos y la reducción de PC en la dieta a niveles del 15,5\% en lechones criados por encima de la zona termoneutra mejoraron el uso de PC. Además, el 15,5\% de la PC en la dieta redujo la excreción de nitrógeno urinario. La retención de $\mathrm{N}$ no se vio afectada por el nivel de PC en la dieta, utilizando el concepto de proteína ideal. El uso de $21 \%$ de PC en la dieta evitó eficazmente la exacerbación de la oxidación de proteínas en cerdos criados por encima de la termoneutralidad.
\end{abstract}

Palabras clave: Aminoácidos; Digestibilidad; Proteína de oxidación; Cerdo; Termoneutralidad; Urea.

\section{Introduction}

Swine are known for their high sensitivity to heat stress, associated with a combination of two factors, inefficient thermoregulatory systems (sweat gland keratinization, presence of subcutaneous fat layer) and intense metabolism (Wolp et al., 2012). Swine breeds used in industrial production, selected for high performance, produce pigs with a greater proportion of muscle tissue compared to no selected pigs. This tends to increase their basal metabolism and, consequently, their production of heat, making them more sensitive to heat stress (Renaudeau et al., 2011)

Conditions in which relative air humidity is approximately $75 \%$ and temperatures are above $24{ }^{\circ} \mathrm{C}$ are considered alert situations, in which measures such as ventilation, triggering of cooling systems and monitoring of animals must be taken. Pigs 
in dry bulb temperatures above $26{ }^{\circ} \mathrm{C}$, relative humidity above $75 \%$ are considered in a danger category by Xin and Harmon (1998). The temperature control measures described above should be intensified, because these temperatures are commonly found in tropical regions of pig production such as Latin America and Southwest Asia. In response, reduction of crude protein content (CP) in diets with the application of ideal protein (IP) concept has been adopted as a nutritional strategy for breeding situations above thermoneutrality (Wolp et al., 2012) to reduce the catabolism of amino acids (AA) and thereby to minimize energy lost as heat (Ferreira et al., 2006; Zuidhof, 2019). Furthermore, the use of the IP concept entails reduced excretion of nitrogen in the environment, which, in addition to being ecologically positive, can improve air quality with reduction of odors from waste (Recharla et al., 2017).

Ideal amino acid profiles recommendations for swine diets under heat stress conditions are not commonly found in nutritional requirements tables. In manuals of nutritional requirements, consideration of heat stress has appeared only recently (Rostagno et al., 2017). Nevertheless, the process of adaptation to heat is biphasic, characterized initially by rapid changes, including changes in feed intake, respiratory and heart rates (Huynh et al., 2005; Renaudeau et al., 2010 and Campos et al. (2017) followed by changes in physiological variables. It is important to evaluate serum variables over time to identify new serum indicators employing rapid methodologies to identify physiology status of pigs raised under temperatures above the thermoneutral zone.

Our hypothesis was the use of low protein diets, based on the ideal protein concept, for piglets raised above the thermoneutrality zone, would confirm the results previously obtained regarding nitrogen balance for pigs under elevated thermal conditions; we also hypothesized that diets high in protein levels would improve serum variables related to hepatic metabolism, enzyme activity related to protein catabolism, and antioxidant activity in serum. Therefore, we measured nutrient balance, nitrogen balance, and serum parameters in pigs in the nursery phase maintained in environments above the thermoneutral zone and fed diets including various levels of $\mathrm{CP}$.

\section{Materials and Methods}

The experiment was conducted in the western region of Santa Catarina $\left(27^{\circ} 12^{\prime} \mathrm{S} 52^{\circ} 37^{\prime} \mathrm{W}\right)$ in the summer. This research had an exploratory and quantitative nature (Pereira et al., 2018).

The project was approved by the Ethics Committee for Animal Well-Being at the State University of Santa CatarinaUDESC, under protocol n $\mathrm{n}^{\circ}$ 01.81.14.

\subsection{Animals/experimental site}

Before the experimental period, all pigs were raised on the same commercial farm, under the same nutritional program and were maintained under same conditions. Fifteen barrows, with mean weight $17.4 \pm 0.9 \mathrm{~kg}$ on d1 and mean weight of 22.8 $\pm 1.6 \mathrm{~kg}$ on $\mathrm{d} 8$ (start of $\mathrm{N}$ balance), were housed individually in metabolism pens (Pekas, 1968), and were distributed in a completely randomized design with three treatments and five replicates.

To simulate breeding conditions in areas above the thermoneutral zone, pigs were maintained in a shed with a semiclimatized environment, equipped with a convective automated heating system (three sets of 1,200-W heaters), programmed to activate at $28{ }^{\circ} \mathrm{C}$ and deactivate at $29^{\circ} \mathrm{C}$. There was a gradual increase of temperature over the first three days from $23{ }^{\circ} \mathrm{C}$ (starting the heaters gradually) and during the excreta collection period, average temperatures were $29.1 \pm 2.3{ }^{\circ} \mathrm{C}$ and relative humidity was $75.5 \pm 4.42 \%$, recorded using dataloggers positioned in the geometric center of the installation with sampling intervals of 30 minutes. Based on Nääs and Cordeiro's (2014) recommendations for temperatures for the comfort zone of pigs $\left(20{ }^{\circ} \mathrm{C}\right.$ and $22^{\circ} \mathrm{C}$ ), the environment was characterized as above the thermoneutral zone during the collection phase. From d18 to $\mathrm{d} 20$ of the experimental period, the heaters were turned off and pigs received the same diet $(18 \% \mathrm{CP})$ and the temperature meet $23 \pm 2{ }^{\circ} \mathrm{C}$. 


\subsection{Treatments}

The treatments were defined as T15, T18, and T21 and consisted of three CP levels, 15.5\%, 18.3\%, and 21\%, respectively. The intermediate level was proposed by Rostagno et al. (2011) and were consider the reference level (Table 1). For the formulation of the diets, nutritional recommendations and nutritional composition were proposed by Rostagno et al. (2011), in which the requirements were met up to the sixth limiting AAs (lysine, methionine, threonine, tryptophan, valine and isoleucine). The AA composition of corn and soybean meal were analyzed previously using high performance liquid chromatography (AOAC, 2002).

To facilitate ingestion, prior to feeding, the diets were moistened with water to $30 \%$ by weight. Three daily feedings, with four-hour intervals starting at $08 \mathrm{~h} 00$, in which feeding was offered ad libitum for 60 minutes or until satiety, after fed water was offered ad libitum.

A period of 8 days was used to adapt the pigs to the experimental environment, with 7 days of total excreta collection and 5 extra days for blood collection, totaling 20 days. In the first 3 days of adaptation, there was a gradual increase of temperature. In the final 2 days of the experiment, the T18 diet $(18 \% \mathrm{CP})$ were provided to all animals.

Table 1. Centesimal, chemical and energetic compositions of experimental diets.

\begin{tabular}{|c|c|c|c|}
\hline & \multicolumn{3}{|c|}{ Treatments (crude protein levels $\mathrm{g} \mathrm{kg}^{-1}$ ) } \\
\hline Ingredients ( $\mathrm{g} \mathrm{kg}^{-1}$ as fed basis) & TA (155) & TB (183) & TC (210) \\
\hline Ground yellow corn & 760.7 & 676.9 & 593.2 \\
\hline Soybean meal $45 \%$ PB & 189.5 & 275.0 & 360.6 \\
\hline Dicalcium phosphate & 14.90 & 14.15 & 13.41 \\
\hline Limestone & 7.80 & 7.81 & 7.82 \\
\hline Soybean oil & 4.02 & 8.65 & 13.28 \\
\hline Starter pig basemix* & 5.00 & 5.00 & 5.00 \\
\hline Mycotoxin adsorbent & 2.00 & 2.00 & 2.00 \\
\hline $\mathrm{NaCl}$ & 4.39 & 4.40 & 4.42 \\
\hline L-Lysine $\mathrm{HCl}$ & 5.37 & 2.78 & 0.18 \\
\hline DL-Methionine & 1.43 & 0.71 & - \\
\hline L-Threonine & 1.65 & 0.83 & - \\
\hline L-Tryptophan & 0.42 & 0.21 & - \\
\hline L-Valine & 1.53 & 0.77 & - \\
\hline L-Isoleucine & 1.29 & 0.64 & - \\
\hline Total & 1000 & 1000 & 1000 \\
\hline \multicolumn{4}{|c|}{ Nutritional composition (calculated as-fed basis) } \\
\hline Crude protein, $\%$ & 15,5 & 18,3 & 21,0 \\
\hline Digestible energy, Mcal $/ \mathrm{kg}$ & 3.38 & 3.39 & 3.39 \\
\hline Metabolizable energy, Mcal $/ \mathrm{kg}$ & 3.23 & 3.23 & 3.23 \\
\hline Lysine digestible, $\%$ & 10.38 & 10.36 & 10.38 \\
\hline Methionine + Cystine digestible, $\%$ & 5.81 & 5.81 & 5.82 \\
\hline Tryptophan digestible, $\%$ & 1.87 & 1.86 & 2.05 \\
\hline Threonine digestible, $\%$ & 6.53 & 6.53 & 6.55 \\
\hline Valine digestible, $\%$ & 6.58 & 6.58 & 7.21 \\
\hline Isoleucine digestible, $\%$ & 5.32 & 5.94 & 6.56 \\
\hline $\mathrm{Ca}, \%$ & 7.34 & 7.34 & 7.33 \\
\hline $\mathrm{P}$ available, \% & 3.64 & 3.64 & 3.63 \\
\hline $\mathrm{Na}, \%$ & 2.00 & 2.01 & 2.00 \\
\hline
\end{tabular}

*Values calculated based on the values obtained from the analysis of the maize and soybean meal provided by the manufacturer or submitted by Rostagno et al. (2011). ${ }^{1}$ Basemix minimum content per kg: Vit. A - 4,167,000 UI, Vit. D3 - 833,000 UI, Vit. E - 13,333 mg, Vit. K3 1,000 mg, Vit. B1 - 1,000 mg, Vit. B2 - 1,667 mg, Vit. B6 - 1,000 mg, Vit. B12 - 8 mg, Niacin - 11,667 mg, Pantothenic acid - 7,333 mg, folic acid - $200 \mathrm{mg}$, Choline - $104 \mathrm{mg}$, Biotin $-33 \mathrm{mg}$, Ca - (min. $166 \mathrm{~g}$, max. $203 \mathrm{~g}$ ), Co - $266.70 \mathrm{mg}, \mathrm{Cu}-66.67 \mathrm{~g}, \mathrm{I}-600 \mathrm{mg}, \mathrm{Mn}-$ 18.33 g, Se -135 mg, Zn -41.67 g, Fe -66.67 g. Source: Authors. 


\subsection{Metabolism/performance}

Urine collections were carried out four times a day to avoid losses by volatilization, following the methodology recommended by Sakomura and Rostagno (2016). The samples were refrigerated, and their masses were measured daily with $10 \%$ of the total volume collected for further analysis.

The chemical and energetic composition of diets, corn, soybean and feces were determined according to AOAC (1984). During feces and urine collection periods, feed intake was calculated, and initial and final weights of the animals were recorded to determine daily feed intake (FI), daily weight gain (WG), and feed:gain ratio (FG).

From the dry matter (DM) values of the diets and feces, as well as the chemical and energetic composition of the diets, corn, soybean, feces and urine, we calculated apparent digestible nutrients and the apparent digestibility and metabolizability coefficients (Sakomura and Rostagno, 2016). Subsequently, we calculated the apparent digestibility coefficient of dry matter (DCDM), the apparent digestibility coefficient of crude protein (DCCP), the apparent digestibility coefficient of organic matter (DCOM), the apparent digestibility coefficient of gross energy (DCGE) and the apparent metabolizability coefficient of gross energy (MCGE).

The values of nitrogen intake (NI), nitrogen output in feces (NOF) and nitrogen output in urine (NOU) were obtained by multiplying nitrogen levels by the amount of feed consumed, excreted in feces and in urine, respectively. From these values, the nitrogen balance (NB = NI $-\mathrm{NOF}-\mathrm{NOU})$, net use of protein (NPU = NB.NI-1) or the metabolizability coefficient of CP and the biological value of dietetic protein (BVFP $=$ NB.(NI - NOF)-1) were calculated according to an adaptation of Adeola (2001), differing in the feeding protocol, in which ad libitum was used to simulate production conditions.

\subsection{Blood sampling and biochemical analysis}

To assess serum variables, the total period of 20 days was divided in six periods: 1 (d 0); 2 (d 4); 3 (d 8); 4 (d 12 ); 5 (d 16), and 6 (d 20). Samples ( $5 \mathrm{~mL}$ ) were obtained by trained staff using jugular venipuncture. Blood sampling were performed prior to the first feeding of the day. Then, serum was obtained by centrifugation $(3,000 \mathrm{rpm} /$ minute $)$ and frozen $\left(-20^{\circ} \mathrm{C}\right)$ until analysis.

Serum was used to evaluate urea $\left(\mathrm{mg} \mathrm{dL}^{-1}\right)$, cholesterol, $\left(\mathrm{mg} \mathrm{dL}^{-1}\right)$, triglycerides $\left(\mathrm{mg} \mathrm{dL}^{-1}\right)$, total protein $\left(\mathrm{mg} \mathrm{dL}^{-1}\right)$, albumin $\left(\mathrm{mg} \mathrm{dL}^{-1}\right)$, alanine aminotransferase $\left(\mathrm{U} \mathrm{L}^{-1}\right)$. Analyses were performed using commercial kits (Analisa $\left.{ }^{\circledR}\right)$, following manufacturer's instructions in a semiautomatic biochemical analyzer (Bioplus 2000®). Globulin levels (mg dL ${ }^{-1}$ ) were calculated as total protein - albumin.

Heat stress can changed as oxidative responses in pigs and the variable ferric reducing ability of plasma-FRAP ( $\mu$ mol $\mathrm{L}^{-1}$ ), thiobarbituric acid reactive substances (TBARS: nmol MAD $\mathrm{mL}^{-1}$ ), and advanced oxidation protein products (AOPP: $\mu$ mol L ${ }^{-1}$ ) were also evaluated. AOPP concentrations (protein oxidation) were determined using a semiautomated method described by Hanasand et al. (2012). Serum levels of FRAP were measured according to the automated technique described by Benzie and Strain (1996). Lipid peroxidation (spectrophotometry at $535 \mathrm{~nm}$ ) was determined as levels of TBARS in serum according to the method described by Jentzsch et al. (1996).

\subsection{Statistical analysis}

A completely randomized design was used, with three protein levels $(15 \%, 18 \%$ and $21 \%)$ with five replicates and one animal per experimental unit. The residues were subjected to Shapiro-Wilk normality tests and the data were logtransformed when necessary to meet the normality assumption. Serum variables were analyzed in two ways, by treatments and by time. Thereafter, variables were subjected to analysis of variance using the statistical package SAS 9.2. P $<0.05$ was considered statistically significant, using the Tukey test. 


\section{Results}

\subsection{Performance, nitrogen balance and digestibility}

There was no effect of treatments (Table 2$)$ on the digestibility coefficients $(\mathrm{P}>0.05)$. The feed: gain ratio was better in the T21 group than in the T15 group $(\mathrm{P}<0.05)$; however, the T18 group did not differ from the other treatments $(\mathrm{P}>0.05)$. There were significantly higher values of nitrogen output in urine, total nitrogen output, and nitrogen digested, and lower biological value of feed protein in the T21 group (Figure 1), followed by the T18 and T15 groups (P <0.05; Table 3). There were no differences among treatments in terms of nitrogen balance $(\mathrm{P}>0.05)$.

Table 2. Performance (means $\pm \mathrm{SE}$ ) and apparent total digestibility of pigs ( $\mathrm{N}$ balance period) fed with different of crude protein levels $(\mathrm{CP})$.

\begin{tabular}{|c|c|c|c|c|}
\hline \multicolumn{5}{|c|}{ Treatments $\left(\mathrm{CP} \mathrm{g} \mathrm{kg}^{-1}\right)$} \\
\hline & TA (155) & TB (183) & TC (210) & P-value \\
\hline \multicolumn{5}{|c|}{ Body weight, $\mathrm{kg}$} \\
\hline Adaptation $(\mathrm{d} 1)$ & $17.8(0.6)$ & $17.2(1.2)$ & $17.1(1.4)$ & 0.747 \\
\hline Start $\mathrm{N}$ balance $(\mathrm{d} 8)$ & $23.9(0.8)$ & $22.1(2.5)$ & $22.2(1.4)$ & 0.334 \\
\hline Finish $\mathrm{N}$ balance (d15) & $28.1(0.9)$ & $26.6(2.3)$ & $26.7(1.5)$ & 0.406 \\
\hline Final period $(d 20)$ & $30.7(0.9)$ & $29.1(2.4)$ & $29.1(2.1)$ & 0.479 \\
\hline \multicolumn{5}{|c|}{ Performance ( $\mathrm{N}$ balance period) } \\
\hline Feed intake, $\mathrm{kg} \mathrm{d}^{-1}$ & $1.10(0.03)$ & $1.05(0.05)$ & $1.02(0.06)$ & 0.197 \\
\hline Weight gain, $\mathrm{kg} \mathrm{d}^{-1}$ & $0.61(0.05)$ & $0.64(0.06)$ & $0.64(0.03)$ & 0.494 \\
\hline Feed:gain ratio & $1.82(0.14) \mathrm{a}$ & $1.66(0.11) \mathrm{ab}$ & $1.59(0.10) b$ & 0.042 \\
\hline \multicolumn{5}{|c|}{ Apparent digestibility coefficients (DC), \% } \\
\hline DCDM, \% & $86.3(1.8)$ & $84.4(1.4)$ & $84.9(1.7)$ & 0.325 \\
\hline DCOM, \% & $88.1(1.9)$ & $86.6(1.6)$ & $87.1(1.8)$ & 0.435 \\
\hline $\mathrm{DCCP}, \%$ & $82.2(4.1)$ & $80.2(3.9)$ & $84.0(3.5)$ & 0.336 \\
\hline DCGE, \% & $85.3(2.4)$ & $83.7(1.9)$ & $84.6(1.7)$ & 0.482 \\
\hline MCGE, $\%$ & $83.4(1.3)$ & $82.1(2.1)$ & $83.0(1.9)$ & 0.570 \\
\hline \multicolumn{5}{|c|}{ Total digestible nutrients } \\
\hline Dry matter, \% & 76.17 & 75.10 & 75.16 & NA \\
\hline Organic matter, $\%$ & 84.16 & 82.25 & 82.52 & NA \\
\hline DE, Mcal kg-1 & 3.33 & 3.30 & 3.34 & NA \\
\hline ME, Mcal kg-1 & 3.25 & 3.24 & 3.28 & NA \\
\hline $\mathrm{CP}, \%$ & 13.54 & 15.28 & 19.03 & NA \\
\hline
\end{tabular}

a, b, c Different letters in the same row differ significantly by the Tukey test $(\mathrm{P}<0.05)$. EPM: Standard error of the mean; DCDM: Apparent digestibility coefficients of dry matter; DCOM: Apparent digestibility coefficients of organic matter; DCCP: Apparent digestibility coefficients of crude protein; DCGE: Apparent digestibility coefficients of gross energy; MCGE: Apparent metabolizable coefficients of gross energy; DE: Digestible energy; ME: metabolizable energy. NA- not analyzed. Source: Authors. 
Table 3. Nitrogen balance in pigs (nursery phase) fed with various proteins levels raised above the thermoneutral zone.

\begin{tabular}{|c|c|c|c|c|}
\hline \multicolumn{5}{|c|}{ Treatments $\left(\mathrm{CP} \mathrm{g} \mathrm{kg}{ }^{-1}\right)$} \\
\hline & TA (155) & TB (183) & $\mathrm{TC}(210)$ & P-values \\
\hline NI, $\mathrm{g} \mathrm{d}^{-1}$ & $25.6(0.8) \mathrm{a}$ & $28.6(1.4) b$ & $32.7(2.0) \mathrm{c}$ & $<0.001$ \\
\hline $\mathrm{NOF}, \mathrm{g} \mathrm{d}^{-1}$ & $4.6(1.0)$ & $5.7(1.3)$ & $5.2(1.1)$ & 0.381 \\
\hline NOU, $\mathrm{g} \mathrm{d}^{-1}$ & $2.7(0.6) \mathrm{a}$ & $3.8(0.3) \mathrm{a}$ & $7.8(1.0) \mathrm{b}$ & $<0.001$ \\
\hline $\mathrm{TNO}, \mathrm{g} \mathrm{d}^{-1}$ & $7.3(0.8) \mathrm{a}$ & $9.5(1.6) \mathrm{a}$ & $13.2(1.5) b$ & $<0.001$ \\
\hline $\mathrm{ND}, \mathrm{g} \mathrm{d}^{-1}$ & $21.0(1.3) \mathrm{a}$ & $22.9(0.9) \mathrm{a}$ & $27.8(2.2) \mathrm{b}$ & $=0.012$ \\
\hline $\mathrm{NB}, \mathrm{g} \mathrm{d}^{-1}$ & $18.3(1.3)$ & $19.1(1.0)$ & $20.0(2.9)$ & 0.478 \\
\hline NPU, \% & 71.5 (3.7) a & $67.0(4.3) \mathrm{ab}$ & $60.1(5.5) b$ & 0.011 \\
\hline BVFP, \% & $87.1(2.8) \mathrm{a}$ & $83.4(1.6) \mathrm{a}$ & $71.5(4.9) \mathrm{b}$ & $<0.001$ \\
\hline
\end{tabular}

a, b, c Different letters in the same row differ statistically from each other by the Tukey test $(\mathrm{P}<0.05)$; NI: Nitrogen intake, NOF: Nitrogen output in feces, NOU: Nitrogen output in urine, TNO: Total nitrogen output (feces and urine), ND: Nitrogen digested, NB: Nitrogen balance, NPU: Net protein utilization, BVFP: Biological value of feed protein. Source: Authors.

Figure 1. Effect of crude protein levels in pigs raised above thermoneutral zone in total nitrogen output-B and biological value of feed protein-C (mean $\pm \mathrm{SD})$. Note: Values followed by different lowercase letters differ according to the Tukey test $(\mathrm{P}<$ $0.05)$.

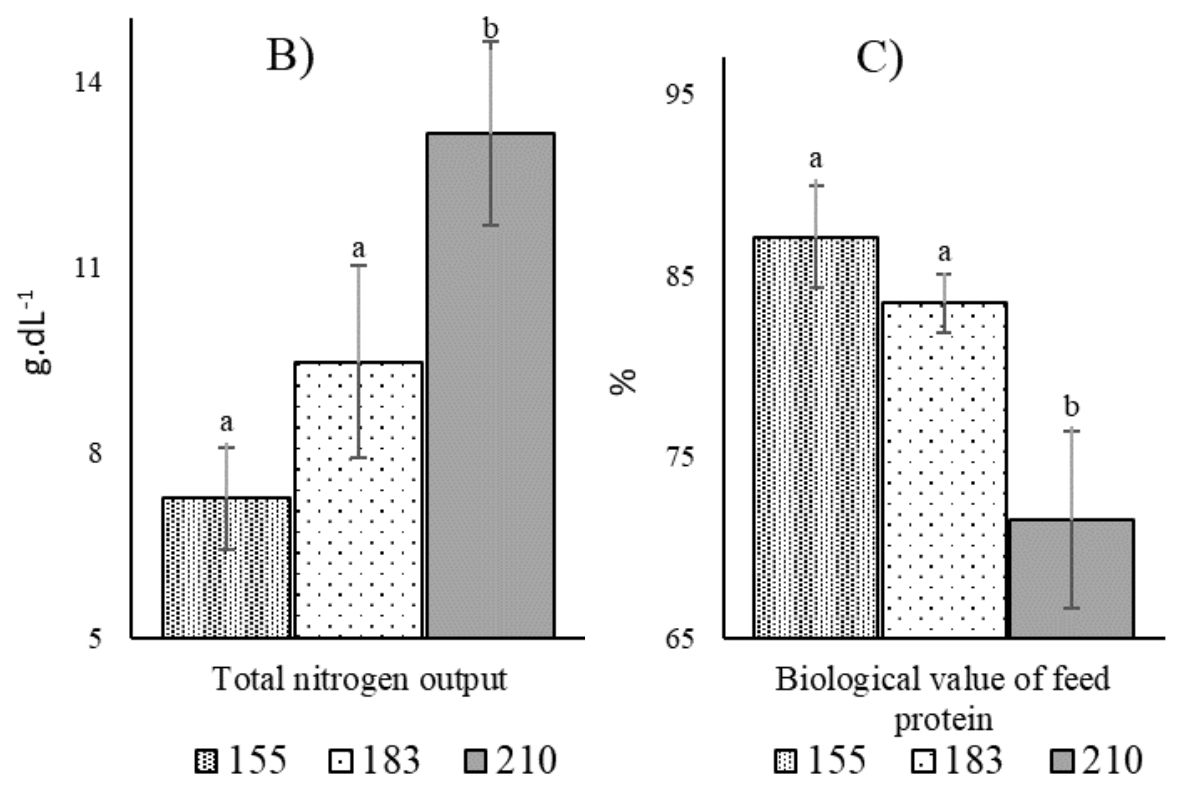

Source: Authors.

\subsection{Biochemistry}

Urea levels differed among treatments on $\mathrm{d} 4,8,12$ and 16 of collection, with the highest averages observed in pigs receiving diets with higher $\mathrm{CP}$ levels $(\mathrm{P}<0.05$; Table 4). On $\mathrm{d} 0$ and $\mathrm{d} 20$, in which the pigs had the same diet, there were no differences among the groups in serum urea levels $(\mathrm{P}>0.05)$. 
Table 4. Variables in pigs (nursery phase) fed with different proteins levels and raising above thermoneutral zone.

\begin{tabular}{|c|c|c|c|c|}
\hline \multicolumn{5}{|c|}{ Treatments $\left(\mathrm{CP} \mathrm{g} \mathrm{kg}{ }^{-1}\right)$} \\
\hline Days & TA (155) & TB (183) & TC (210) & P-values \\
\hline \multicolumn{5}{|c|}{ Urea $\left(\mathrm{mg} \mathrm{dL}^{-1}\right)$} \\
\hline 0 & $38.14(8.5)^{\mathrm{A}}$ & $31.44(1.9)^{\mathrm{A}}$ & $38.46(10.5)^{\mathrm{A}}$ & 0.358 \\
\hline 4 & $7.15(6.5) c^{C}$ & $19.12(4.7) b^{B}$ & $29.86(6.4) \mathrm{a}^{\mathrm{AB}}$ & 0.001 \\
\hline 8 & $6.02(3.9) c^{C}$ & $15.06(6.3) b^{B C}$ & $24.26(10.2) \mathrm{a}^{\mathrm{C}}$ & 0.001 \\
\hline 12 & $7.15(4.3) \mathrm{c}^{\mathrm{C}}$ & $18.04(7.8) b^{B C}$ & $36.57(8.7) \mathrm{a}^{\mathrm{AB}}$ & 0.001 \\
\hline 16 & $6.35(2.1) c^{C}$ & $17.00(5.5) b^{B C}$ & $28.97(2.3) \mathrm{a}^{\mathrm{BC}}$ & 0.001 \\
\hline 20 & $14.95(1.0)^{\mathrm{B}}$ & $13.16(3.3)^{\mathrm{C}}$ & $14.88(3.6)^{\mathrm{D}}$ & 0.854 \\
\hline P-value & 0.001 & 0.001 & 0.001 & \\
\hline \multicolumn{5}{|c|}{ Cholesterol $\left(\mathrm{mg} \mathrm{dL}^{-1}\right)$} \\
\hline 0 & $47.40(7.7)^{\mathrm{B}}$ & $48.80(13.2)^{\mathrm{C}}$ & $46.20(5.8)^{\mathrm{C}}$ & 0.845 \\
\hline 4 & $62.20(6.7) \mathrm{a}^{\mathrm{A}}$ & $60.60(3.0) \mathrm{ab}^{\mathrm{AB}}$ & $54.60(6.9) \mathrm{b}^{\mathrm{BC}}$ & 0.020 \\
\hline 8 & $60.20(10.3)^{\mathrm{A}}$ & $63.80(13.5)^{\mathrm{AB}}$ & $52.20(5.6)^{\mathrm{BC}}$ & 0.195 \\
\hline 12 & $68.00(7.5)^{\mathrm{A}}$ & $54.40(11.5)^{\mathrm{BC}}$ & $52.60(12.7)^{\mathrm{BC}}$ & 0.052 \\
\hline 16 & $65.75(6.1)^{\mathrm{A}}$ & $67.60(13.6)^{\mathrm{A}}$ & $68.00(12.2)^{\mathrm{A}}$ & 0.804 \\
\hline 20 & $61.75(13.0)^{\mathrm{AB}}$ & $74.00(12)^{A}$ & $64.20(7.2)^{\mathrm{AB}}$ & 0.395 \\
\hline P-value & 0.044 & 0.002 & 0.001 & \\
\hline \multicolumn{5}{|c|}{ Triglycerides $\left(\mathrm{mg} \mathrm{dL}^{-1}\right)$} \\
\hline 0 & $45.40(15.7)^{\mathrm{A}}$ & $45.80(5.6)$ & $38.00(15.3)^{\mathrm{AB}}$ & 0.657 \\
\hline 4 & $48.00(11.0)^{\mathrm{A}}$ & $44.20(9.6)$ & $47.80(11.7)^{\mathrm{A}}$ & 0.792 \\
\hline 8 & $30.80(6.4)^{B}$ & $40.60(15.5)$ & $31.40(3.6)^{\mathrm{B}}$ & 0.398 \\
\hline 12 & $41.33(4.1)^{\mathrm{A}}$ & $41.60(22.4)$ & $45.75(9.2)^{\mathrm{A}}$ & 0.601 \\
\hline 16 & $41.25(10.4)^{\mathrm{AB}}$ & $52.40(22.2)$ & $52.60(27.3)^{\mathrm{AB}}$ & 0.709 \\
\hline 20 & $29.75(5.8)^{\mathrm{B}}$ & $44.40(10.3)$ & $38.50(7.4)^{\mathrm{AB}}$ & 0.085 \\
\hline P-value & 0.039 & 0.156 & 0.036 & \\
\hline
\end{tabular}

*Blood urea; cholesterol; triglyceride; Values followed by different lowercase letters $(\mathrm{a}, \mathrm{b}, \mathrm{c})$ in the lines differ according to the Tukey test (P $<0.05)$, as well as different subscript letters $(\mathrm{A}, \mathrm{B}, \mathrm{C})$ in the same column differ from each other over the time $(\mathrm{P}<0.05)$. Source: Authors.

On d4, cholesterol levels were higher in the T15 group than in the T21 group ( $\mathrm{P}<0.05$; Table 4). On the other days, there were no differences between treatments $(\mathrm{P}>0.05$; Table 4). During these days, there was an increase in cholesterol levels compared to levels on $\mathrm{d} 0$ (the period in which the animals began consuming the experimental diets). Triglyceride levels did not differ between treatments ( $\mathrm{P}>0.05$ ); however, there were differences throughout the collection days in the T15 and T21 groups (P <0.05; Table 4). Total protein, albumin and globulin levels and alanine aminotransferase activity did not differ between groups or over time $(\mathrm{P}>0.05$; Table 6$)$.

TBARS and AOPP levels did not differ between treatments. FRAP levels were lower in the T18 group than in the T21 only on $\mathrm{d} 4$ (P >0.05; Table 5). There was a variation in the levels of TBARS, AOPP and FRAP during the days when FRAP showed the lowest value on d8, compared to d12 for the T15 and T21 groups, as well as a better value on d16 for the T18 group ( $\mathrm{P}<0.05$; Table 5). There were variations in TBARS levels throughout the experimental period, where the lowest values were observed at the first collection for all treatments, similar to those of d20 and d12, for T15 and T21, respectively. AOPP levels were higher on d16 for T15; however, for T18 and T21, the values were higher on d20 (Figure 2). 
Table 5. Biochemical variables of piglets raised above the thermoneutral zone fed diets with different levels of protein.

\begin{tabular}{|c|c|c|c|c|}
\hline \multicolumn{5}{|c|}{ Treatments $\left(\mathrm{CP} \mathrm{g} \mathrm{kg}{ }^{-1}\right)$} \\
\hline Days & TA (155) & TB (183) & $\mathrm{TC}(210)$ & P-value \\
\hline \multicolumn{5}{|c|}{$\operatorname{FRAP}\left(\mu \mathrm{mol} \mathrm{L}^{-1}\right)$} \\
\hline 0 & $509(216)^{\mathrm{AB}}$ & $420(207)^{\mathrm{ABC}}$ & $411(112)^{\mathrm{BC}}$ & 0.468 \\
\hline 4 & $472(134) a b^{\mathrm{AB}}$ & $313(84) b^{B C}$ & $613(66) \mathrm{a}^{\mathrm{A}}$ & 0.014 \\
\hline 8 & $299(174)^{\mathrm{B}}$ & $237(102)^{\mathrm{C}}$ & $297(48)^{\mathrm{C}}$ & 0.654 \\
\hline 12 & $590(109)^{\mathrm{A}}$ & $351(204)^{\mathrm{ABC}}$ & $505(71)^{\mathrm{B}}$ & 0.081 \\
\hline 16 & $417(230)^{\mathrm{AB}}$ & $642(132)^{\mathrm{A}}$ & $526(261)^{\mathrm{AB}}$ & 0.147 \\
\hline 20 & $558(284)^{\mathrm{AB}}$ & $487(83)^{\mathrm{AB}}$ & $489(103)^{\mathrm{AB}}$ & 0.365 \\
\hline P-value & 0.025 & 0.001 & 0.001 & \\
\hline \multicolumn{5}{|c|}{ TBARS (nmol MAD mL ${ }^{-1}$ ) } \\
\hline 0 & $15.0(3.5)^{\mathrm{B}}$ & $15.9(4.3)^{\mathrm{B}}$ & $17.8(4.0)^{\mathrm{B}}$ & 0.875 \\
\hline 4 & $24.2(7.4)^{\mathrm{A}}$ & $23.6(2.7)^{\mathrm{A}}$ & $25.0(14.6)^{\mathrm{AB}}$ & 0.506 \\
\hline 8 & $17.2(5.5)^{\mathrm{AB}}$ & $23.0(8.7)^{\mathrm{AB}}$ & $26.8(23.0)^{\mathrm{AB}}$ & 0.637 \\
\hline 12 & $23.4(4.4)^{\mathrm{A}}$ & $20.6(4.0)^{\mathrm{AB}}$ & $17.1(3.6)^{\mathrm{B}}$ & 0.074 \\
\hline 16 & $24.0(5.6)^{\mathrm{A}}$ & $22.2(5.6)^{\mathrm{A}}$ & $23.6(1.6)^{\mathrm{A}}$ & 0.912 \\
\hline 20 & $15.8(6.2)^{\mathrm{B}}$ & $23.6(8.3)^{\mathrm{AB}}$ & $20.5(3.4)^{\mathrm{AB}}$ & 0.129 \\
\hline P-value & 0.039 & 0.027 & 0.018 & \\
\hline \multicolumn{5}{|c|}{ AOPP $\left(\mu \mathrm{mol} \mathrm{L}^{-1}\right)$} \\
\hline 0 & $32.4(9.3)^{\mathrm{B}}$ & $29.9(7.8)^{\mathrm{AB}}$ & $26.4(5.5)^{\mathrm{AB}}$ & 0.428 \\
\hline 4 & $22.8(3.9)^{\mathrm{B}}$ & $31.7(7.4)^{\mathrm{AB}}$ & $30.2(17.5)^{\mathrm{AB}}$ & 0.265 \\
\hline 8 & $21.0(4.7)^{\mathrm{B}}$ & $20.4(5.9)^{\mathrm{B}}$ & $21.6(6.2)^{\mathrm{B}}$ & 0.904 \\
\hline 12 & $24.9(6.7)^{\mathrm{B}}$ & $19.7(8.3)^{\mathrm{B}}$ & $25.0(8.4)^{\mathrm{AB}}$ & 0.706 \\
\hline 16 & $63.4(24.5)^{\mathrm{A}}$ & $46.4(32.2)^{\mathrm{AB}}$ & $28.1(8.4)^{\mathrm{AB}}$ & 0.062 \\
\hline 20 & $27.8(8.3)^{\mathrm{B}}$ & $51.6(33.8)^{\mathrm{A}}$ & $56.7(31.6)^{\mathrm{A}}$ & 0.156 \\
\hline $\mathrm{P}$-value & 0.011 & 0.043 & 0.050 & \\
\hline
\end{tabular}

*Antioxidant power of iron reduction (FRAP); Thiobarbituric acid reactive substances (TBARS); Advanced oxidation protein products (AOPP); Values followed by different lowercase letters $(\mathrm{a}, \mathrm{b}, \mathrm{c})$ in the lines differ by the Tukey test $(\mathrm{P}<0.05)$, as well as different subscript letters (A, B, C) in the same column differ from each other over the time $(\mathrm{P}<0.05)$. Source: Authors 
Table 6. Blood variables of piglets raised above the thermoneutral zone with diets with different levels of protein.

\begin{tabular}{|c|c|c|c|c|}
\hline \multicolumn{5}{|c|}{ Treatments $\left(\mathrm{CP} \mathrm{g} \mathrm{kg}^{-1}\right)$} \\
\hline Days & TA (155) & TB (183) & TC (210) & P-value \\
\hline \multicolumn{5}{|c|}{ Total protein $\left(\mathrm{mg} \mathrm{dL}^{-1}\right)$} \\
\hline 0 & $7.38(0.9)$ & $7.03(0.5)$ & $7.20(1.2)$ & 0.659 \\
\hline 4 & $6.86(0.9)$ & $7.22(0.5)$ & $6.78(0.4)$ & 0.365 \\
\hline 8 & $6.58(1.2)$ & $5.56(1.1)$ & $7.00(0.7)$ & 0.084 \\
\hline 12 & $6.40(0.6)$ & $6.55(0.8)$ & $6.74(0.6)$ & 0.846 \\
\hline 16 & $8.93(1.1)$ & $7.15(0.6)$ & $7.34(0.5)$ & 0.367 \\
\hline 20 & $6.90(0.6)$ & $6.94(0.5)$ & $7.43(0.6)$ & 0.214 \\
\hline P-value & 0.067 & 0.568 & 0.429 & \\
\hline \multicolumn{5}{|c|}{ Albumin $\left(\mathrm{mg} \mathrm{dL}^{-1}\right)$} \\
\hline 0 & $2.08(0.27)^{\mathrm{AB}}$ & $2.05(0.20)^{\mathrm{AB}}$ & $1.96(0.5)^{\mathrm{AB}}$ & 0.804 \\
\hline 4 & $1.98(0.36)^{\mathrm{AB}}$ & $1.92(0.31)^{\mathrm{AB}}$ & $2.04(0.40)^{\mathrm{AB}}$ & 0.856 \\
\hline 8 & $1.76(0.4)^{\mathrm{B}}$ & $1.76(0.26)^{\mathrm{B}}$ & $1.86(0.26)^{\mathrm{B}}$ & 0.764 \\
\hline 12 & $1.93(0.49)^{\mathrm{AB}}$ & $1.93(0.46)^{\mathrm{AB}}$ & $2.36(0.18)^{\mathrm{AB}}$ & 0.203 \\
\hline 16 & $2.03(0.75)^{\mathrm{AB}}$ & $2.20(0.36)^{\mathrm{A}}$ & $2.25(0.58)^{\mathrm{AB}}$ & 0.417 \\
\hline 20 & $2.43(0.36)^{\mathrm{A}}$ & $2.04(0.56)^{\mathrm{AB}}$ & $2.80(0.42)^{\mathrm{A}}$ & 0.267 \\
\hline P-value & 0.036 & 0.050 & 0.041 & \\
\hline \multicolumn{5}{|c|}{ Globulin $\left(\mathrm{mg} \mathrm{dL}^{-1}\right)$} \\
\hline 0 & $5.30(0.8)$ & $4.98(2.2)$ & $5.24(1.5)$ & 0.364 \\
\hline 4 & $4.88(0.7)$ & $5.30(0.6)$ & $4.74(0.7)$ & 0.478 \\
\hline 8 & $4.82(1.1)$ & $3.80(1.0)$ & $5.14(0.8)$ & 0.114 \\
\hline 12 & $4.48(0.42)$ & $4.63(0.9)$ & $4.38(0.7)$ & 0.657 \\
\hline 16 & $6.89(1.9)$ & $4.95(1.0)$ & $5.09(0.9)$ & 0.206 \\
\hline 20 & $4.48(0.9)$ & $4.90(0.8)$ & $4.63(0.3)$ & 0.847 \\
\hline P-value & 0.196 & 0.095 & 0.369 & \\
\hline \multicolumn{5}{|c|}{ Alanine aminotransferase $\left(\mathrm{U} \mathrm{L}^{-1}\right)$} \\
\hline 0 & $41.4(19)$ & $48.4(27.7)$ & $47.2(17.5)$ & 0.502 \\
\hline 4 & $32.2(9.4)$ & $30.8(8.4)$ & $33.6(14.2)$ & 0.367 \\
\hline 8 & $35.4(5.3)$ & $36.6(3.9)$ & $29.4(9.8)$ & 0.306 \\
\hline 12 & $35.8(3.1)$ & $33.8(6.1)$ & $34.0(15.7)$ & 0.748 \\
\hline 16 & $37.5(7.7)$ & $50.0(13.8)$ & $34.0(7.4)$ & 0.185 \\
\hline 20 & 45.5 (11.4) & $42.0(9.9)$ & $42.2(20.5)$ & 0.841 \\
\hline $\mathrm{P}$-value & 0.259 & 0.025 & 0.124 & \\
\hline
\end{tabular}

Values followed by different lowercase letters $(\mathrm{a}, \mathrm{b}, \mathrm{c})$ in the lines differ by the Tukey test $(\mathrm{P}<0.05)$, as well as different subscript letters $(\mathrm{A}$,

$\mathrm{B}, \mathrm{C})$ in the same column differ from each other over the time $(\mathrm{P}<0.05)$. Source: Authors 
Figure 2. Effect of crude protein level $\left(\mathrm{g} \cdot \mathrm{kg}^{-1}\right)$ for pigs raised above the thermoneutral zone terms of advanced oxidation protein products-APOP (mean $\pm \mathrm{SD}$ ). Note: Values followed by different lowercase letters in the day differ according to the Tukey test $(\mathrm{P}<0.05)$, and various capital letters $(\mathrm{A}, \mathrm{B})$ differ from each other over the time $(\mathrm{P}<0.05)$ in the same treatment.

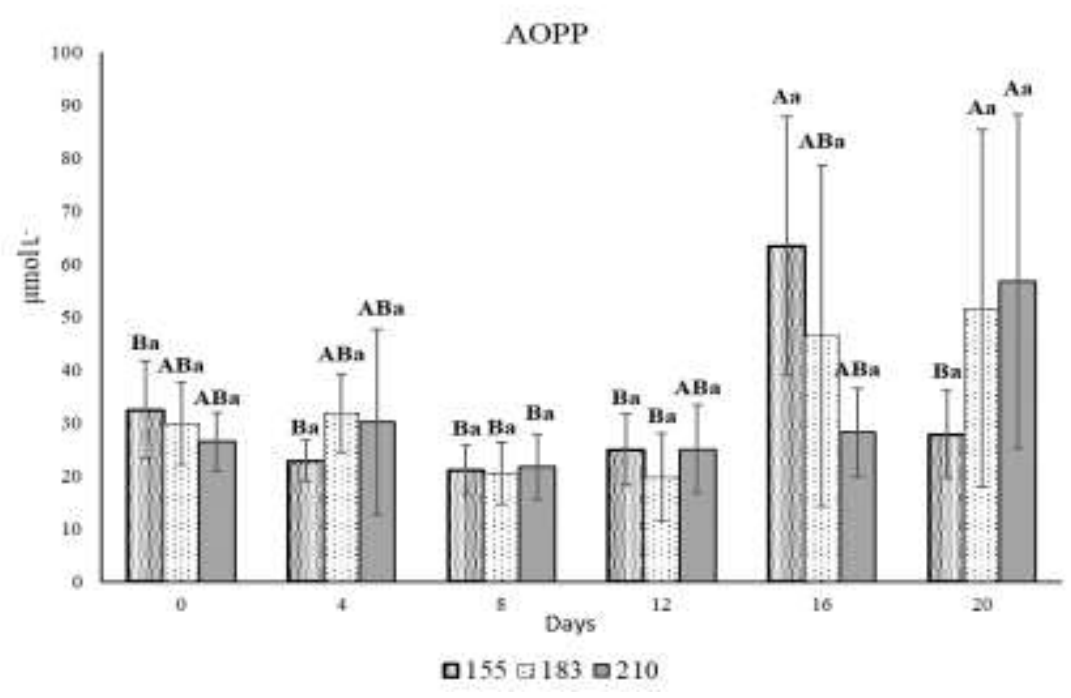

Source: Authors

\section{Discussion}

The lack of effects on FI and WG between treatments and the better FG obtained for the T21 group were not expected, because when pigs are subjected to heat stress, there is a reduction in voluntary FI in order to reduce the heat increment (HI) of feeding (Cervantes et al., 2018). Diets with higher CP content result in greater use of excess AA and are energetically less efficient than other nutrients, thereby increasing the HI by about $+1.7 \mathrm{kcal}$ per $\mathrm{g}$ of protein intake (Le Bellego et al., 2001). This could affect the FI for the T21 pigs, consequently reducing gain and worsening FG, a result different from what we observed in the present study.

The absence of a difference may be associated with the ambient temperature used, adjusted to simulate a farm production condition; however, the temperature used may not have been sufficiently high to alter feed intake, and/or metabolic adaptation mechanisms or cardiovascular system changes (Renaudeau et al., 2012) were sufficient for adaptation to environmental conditions. This may explain the minimal effects of temperature on FI.

An important observation about FG must be made, the AA profile used for the calculation of the diets (Rostagno et al., 2011) were developed for pigs raised in thermoneutral conditions, different from those used in the experiment, in which the animals were maintained above thermoneutrality. Pigs raised above thermoneutrality, because they require adaptations to heat conditions, including greater relative visceral weight (Tavares et al., 2000), probably had altered nutritional requirements with respect to the AA profile. Consequently, animals in the T15 and T18 treatment groups may have been given inadequate quantities of AA, possibly impairing muscle growth. As a result, T21 was the treatment group with the lowest limitation and the one with the best FG compared to TA.

Another possibility was the other AA started to be limiting in the low protein treatment (T15). Wang et al. (2018) reported that the five first essential amino acids requirements (lysine, threonine, sulfur-containing AAs, tryptophan, and valine) in low protein diets were higher than in requirements for pigs fed conventional crude protein levels, because the need for nitrogen for endogenous synthesis of non-essential AA to support protein synthesis may be increased when dietary CP is lowered.

However, low protein diets associated with use of free amino acids can reduce the incidence of gut disorders (Gloaguen et al. (2014). The pigs in the treatments T15, T18, and T2, received 5.8, 2.5, and 0.1\% of total crude protein from 
free AA, respectively. However, Wang et al. (2018) pointed out that a very low protein diet can reduce performance due to a deficiency in intact protein or excess free AA.

In addition, the raising conditions used in this study (pigs housed in individual pens) may have changed the pattern consumption behavior and may not reflect the conditions observed in collective pens. According to Hyun and Ellis (2001), the number of animals in each pen can alter zootechnical performance. De Haer and Vries (1993) observed the influence of pig accommodation on the pattern of FI. Although feeding was offered until apparent satiety, it was carried out three times per day, possibly limiting consumption, and consequently WG. This hypothesis is reinforced by the results of Quiniou et al. (2000) in a study with growing pigs, raised at $29^{\circ} \mathrm{C}$, found that the animals consumed about 9.9 meals/d when fed ad libitum. The improvement in FG reinforces the hypothesis presented previously, to the effect that temperature above thermoneutrality may have altered AA requirements, resulting in better FG for the diets with higher CP content, possibly also associated with the higher nitrogen digested values for pigs fed diets with $21 \% \mathrm{CP}$. Another point to consider is the likely benefit of non-essential AA, especially in diets with $21 \% \mathrm{CP}$.

Our results were different from those reported by Oliveira et al. (2007) in a study of early-stage pigs maintained in thermoneutral or high-temperature environments; they found no differences in FG. Our results showed an improvement in FG in diets with more protein, emphasizing the need for new studies related to AA profiles for animals raised above the thermoneutral zone, in order to maximize zootechnical performance.

The values of IN were lower in the treatments with lower protein contents, possibly attributable to the various levels of CP and the same FI between the treatments. The higher values of N output (NOU and TNO) were expected in treatments with higher CP, especially because the increase in protein content was achieved using increases in non-essential AA levels. This behavior is relatively common in the literature when various levels of protein or protein quality are tested in pig diets, with higher values of excretion for the treatments with higher protein content or worse profiles of AA (Orlando et al., 2007; Ceron et al., 2013; Freitag et al., 2014).

The same behavior, reduction of nitrogen excretion with the reduction of $\mathrm{CP}$ in the diet, was reported by Wang et al. (2018). These authors argued of the best use of protein is related to the composition of diets with lower protein content, among which is the reduction of soybean meal and, consequently, of antinutrient factors tend to contribute to better absorption and utilization of amino acids.

Likewise, the NPU (equivalent to the metabolizable coefficient of crude protein) and BVFP were better for the T15 group when compared to the $21 \%$ level, reinforcing the hypothesis that the AA provided to the T18 and T21 groups were not used in their total for muscle synthesis, but rather for catabolism and as an energy source, corroborated by the higher values of nitrogen excreted from the treatments with higher crude protein content. Ceron et al. (2013) obtained similar responses and reported lower nitrogen content excreted in piglets with diets with lower protein levels.

The highervalues of BUN in pigs fed diets with higher CP content were associated with the lowest efficiency of the use of nitrogen for muscle protein synthesis, because BUN is an important indicator of efficiency or inefficiency in the use of AA for protein synthesis (Fraga et al., 2008). Similar results were found by Toledo et al. (2014), who reported reduction of blood urea levels with the reduction of $\mathrm{CP}$ levels in pigs with lower protein content diets. This response was associated with catabolism of excess amino acids and conversion of the amino group to urea in the liver for subsequent renal excretion. The blood nitrogen results are consistent with the results obtained for the nitrogen balance in which the T15 group showed lower urinary excretion and total nitrogen and better values of NPU and BVFP. The similar values of blood urea levels on days 0 and 20 of the experiment were related to all animals receiving a diet with the same protein content, reinforcing the relevance of this indicator for the evaluation of the use of AA for protein synthesis. 
Cholesterol levels were higher in the T15 group only on d4, and FRAP levels were lower in the T18 group than in the T21 group. The difference observed on d 4 may have been associated with the adaptation of the animals to the experimental environment. According to Campos et al. (2017), the process of adaptation to high temperatures is biphasic, in the first 48 hours after exposure, there was an increase in the internal temperature, an increase in heat losses and lower heat production associated with reduction in feed intake may have contributed to the differences in cholesterol and FRAP. The absence of effect on these variables, according to Campos et al. (2017), was a consequence of adaptation to heat; this is the stage of reduction in thyroid hormone levels and reduction of endogenous heat production. Freitag et al. (2014) obtained similar results, where protein reduction in the diet had no effect on plasma cholesterol levels in piglets raised under heat stress.

Increases in protein oxidation in the T15 group on day 16 of the experiment may have been associated with the accumulation of heat stress over time. According to Celi and Gaba (2015), heat stress and nutritional imbalances may result in increases in reactive oxygen metabolites (ROS) may promote increased protein oxidation. Therefore, we believe that the difference in the T15 group was associated with the combination of heat stress and protein limitation (previously discussed for FC), which, when combined, causes increased oxidation processes. The increases of protein levels in the diets of the T15 group piglets on $\mathrm{d} 18$ to $18 \%$ of $\mathrm{CP}$ and the reestablishment of the thermoneutral conditions, the piglets in the T15 group obtained sufficient conditions for AOPP to return to normal.

Our results confirm the biphasic adaptation of pigs to hot environmental conditions, as proposed by Campos et al. (2017), and suggest AOPP may be indicators of medium-term stress and nutritional limitation for pigs. Furthermore, under commercial conditions, in which heat stress is usually intermittent and there is usually wasteful accumulation in the facilities (under slatted floors), treatments with lower protein levels, because they guarantee lower caloric increases and better air quality (lower production of ammonia from the fermentation of waste), would generate better performance.

\section{Conclusion}

Amino acid supplementation and reduction of crude protein in the diet to levels of $15.5 \%$ in piglets raised above the thermoneutral zone improved the use of crude protein. Furthermore, $15.5 \%$ of crude protein in the diet reduced the excretion of urinary nitrogen. The use of $21 \%$ crude protein in the diet efficiently avoided exacerbation of protein oxidation for pigs raised above thermoneutrality.

\section{Acknowledgements}

The authors are grateful for the support of the Coordination of Superior Level Staff Improvement (CAPES), the Mato Grosso do Sul State University- UEMS, the Santa Catarina State University -UDESC, Ajinomoto Animal Nutrition for the supply of amino acids and laboratory support and Demétrio Baldissarela Agricultural College School administration.

\section{Conflict of interest}

The authors declare no conflict of interest.

\section{References}

Adeola, O. (2001). Digestion and balance techniques in pigs. In: Lewis, A. J., Sourthern, L. L. Swine nutrition, (2nd ed.), Boca Raton: CRC, 903-916. AOAC (1984). Association of Official Analytical Chemists (AOAC). Official methods of analysis, (14th ed.). Arlington.

AOAC (2002). Association of Official Analytical Chemist (AOAC). Official methods of analysis, (17th ed.), AOAC Inc. Arlington, VA, USA. 
Benzie, I. F. F., \& Strain, J. J. (1996). The ferric reducing ability of plasma (FRAP) as a measure of "antioxidant power": the FRAP assay. Anal. Biochem. $239,70-76$

Campos, P. H. R .F., LE Floc'h, N., Noblet, J., \& Renaudeau, D. (2017). Physiological responses of growing pigs to high ambient temperature and/or inflammatory challenges. R. Bras. Zootec. 46, 37-544.

Celi, P., \& Gaba, G. (2015). Oxidant/antioxidant balance in animal nutrition and health: the role of protein oxidation. Front. Vet. Sci. 2, 48.

Ceron, M. S., Oliveira, V., Lovatto, P. A., \& Vale, M. M. (2013). Maintenance requirement and deposition efficiency of lysine in pigs. Pesq. Agropec. Bras. $48,1269-1274$.

Cervantes, M., Antoine, D., Valle, J. A., Vásquez, N., Camacho, R. L., Bernal, H., \& Morales, A. (2018). Effect of feed intake level on the body temperature of pigs exposed to heat stress conditions. J. Therm. Biol. 76, 1-7.

De Haer, L. C. M., \& De Vries, A. G. (1993). Feed intake patterns of and feed digestibility in growing pigs housed individually or in groups. Livest. Prod. Sci. $33,277-292$.

Ferreira, R. A., Oliveira, R. F. M., Donzele, J. L., Araújo, C. V., Silva, F. C. O., Vaz, R. G. M. V., \& Rezende, W. O. (2006). Effect of feeding reduced crude protein, amino acid-supplemented diets on performance of castrated swine from 15 to $30 \mathrm{~kg}$ on high environmental temperature. R. Bras. Zootec. 35, 10561062 .

Fraga, A. L., Moreira, I., Furlan, A. C., Bastos, A. O., Oliveira, R. P., \& Murakami, A. E. (2008). Lysine requirement of starting barrows from two genetic groups, fed on low crude protein diets. Braz. Arch. Biol. Technol. 51, 49-56.

Freitag, D. C., Klosowski, E. S., Pozza, P. C., Oliveira, A. C., Tsutsumi, C. Y., Nunes, R. V., \& Sangali, C. P. (2014). Reducing crude protein in diets on the metabolic balances for pigs kept in different thermal conditions. Semina: Ciênc. Biol. Saúde. 35, 61-70.

Gloaguen, M., Le Floc'h, N., Corrent, E., Primot, Y., \& Van Milgen, J. (2014). The use of free amino acids allows formulating very low crude protein diets for piglets. J Anim Sci. 92(2):637-644.

Hanasand, M., Omdal, R., Norheim, K. B., Goransson, L. G., \& Brede, C. (2012). Improved detection of advanced oxidation protein products in plasma. Clin. Chim. Acta. 413, 901-906.

Huynh, T. T. T., Aarninka, A. J. A., Gerritsc, W. J. J., Heetkampd, M. J. H., Canhe, T. T., Spoolderf, H. A. M., Kempd, B., \& Verstegenc, M. W. A. (2005). Thermal behavior of growing pigs in response to high temperature and humidity. Appl. Anim. Behav. Sci. 91, 1-16.

Hyun, Y., \&Ellis. M. (2001). Effect of group size and feeder type on growth performance and feeding patterns in growing pigs. J. Animal Sci. 79, 803-810.

Jentzsch, A. M., Bachmann, H., Furst, P., \& Biesalski, H. (1996). Improved analysis of malondialdehyde in human body fluids. Free Radical Bio. Med. 20, $251-256$

Le Bellego, L., Van Milgen, J., \&Noblet, J. (2001). Energy utilization of low protein diets in growing pigs. J. Animal Sci. 79, 1259-1271.

Nääs, I. A., Cordeiro, A. F. S. Ambiência na fase de creche. In: Produção de suínos Teoria e prática. In: Ferreira, A. D., Carraro, B., Dallanora, D., Machado, D., Machado, I. P., Pinheiro, R., Rohr, S., 2014. Produção de suínos: teoria e prática. ABCS, 633-635.

Oliveira, V., Fialho, E. T., Lima, J. A. F., \& Araújo, J. S. (2007). Nitrogen metabolism of swine fed with low crude protein diets. R. Bras. Agrociência. 13, 257-260.

Orlando, U. A. D., Oliveira, R. F. M., Donzele, J. L., Ferreira, R. A., Silva, F. C. O., Vieira Vaz, R. G. M. V., \& Siqueira, J. C. (2007). Crude protein levels and amino acid supplementation in diets of gilts maintained in a high environmental temperature from 60 to $100 \mathrm{~kg}$. R. Bras. Zootec. 36, 1069-1075.

Pekas, J. C. (1968). Versatile swine laboratory apparatus for physiologic and metabolic studies. J. Animal Sci. 27, 1303-1309.

Pereira, A. S., Shitsuka, D. M., Pereira, F. J. \& Shitsuka R. (2018). Methodology of cientific research. UAB / NTE / UFSM Editors. https://repositorio.ufsm.br/bitstream/handle/1/15824/Lic_Computacao_Metodologia-Pesquisa-Cientifica.pdf?sequence=1.

Quiniou, N., Dubois, S., \& Noblet, J. (2000). Voluntary feed intake and feeding behaviour of group-housed growing pigs are affected by ambient temperature and body weight. Livest. Prod. Sci. 63, 245-253.

Recharla, N., Kim, K., Park, J., Jeong, J., Jeong, Y., Lee, H., Hwang, O., Ryu, J., Baek, Y., Oh, Y., \& Park, S. (2017). Effects of amino acid composition in pig diet on odorous compounds and microbial characteristics of swine excreta. J. Anim. Sci. Technol. 59, 1-8.

Renaudeau, D., Anais, C., Tel, L., \& Gourdine, J. L. (2010). Effect of temperature on thermal acclimation in growing pigs estimated using a nonlinear function. J. Animal Sci. 88, 3715-3724.

Renaudeau, D., Collin, A., Yahav, S., Basilio, V., Gourdine, J. L., \& Collier, R. J. (2012). Adaptation to hot climate and strategies to alleviate heat stress in livestock production. Animal. 6, 707-728.

Renaudeau, D., Gourdine, J. L., \& St-Pierre, N. R. (2011). A meta-analysis of the effects of high ambient temperature on growth performance of growingfinishing pigs. J. Animal Sci. 89, 2220- 2230.

Rostagno, H. S., Albino, L. F. T., Donzele, J. L. Sakomura, N. K., Perazzo, F. G., Saraiva, A., Teixeira. M. L., Rodrigues, P. B., Oliveira, R. F., Barreto, S. L. R., \& Brito, C. O. (2017). Tabelas Brasileiras para Aves e Suínos. Composição de Alimentos e Exigências Nutricionais (4a ed.), UFV, 488.

Rostagno, H. S., Albino, L. F. T., Donzele, J. L., Gomes, P. C., Oliveira, R. F., Lopes, D. C., Ferreira, A. S., Barreto, S. L. T., \& Euclides, R. F. (2011). Tabelas Brasileiras para Aves e Suínos. Composição de Alimentos e Exigências Nutricionais. Editora UFV, 252. 
Research, Society and Development, v. 10, n. 1, e21210111345, 2021

(CC BY 4.0) | ISSN 2525-3409 | DOI: http://dx.doi.org/10.33448/rsd-v10i1.11345

Sakomura, N. K., \& Rostagno, H. S. (2016). Métodos de pesquisa em nutrição de monogástricos. FUNEP (2a ed.), 262p.

Tavares, S. L. S., Donzele, J. L., Oliveira, R. F. M., \& Ferreira, A. S. (2000). Influence of Environment Temperature on the Performance and the Physiological Traits of Barrows from 30 to $60 \mathrm{~kg}$. R. Bras. Zootec. 29, 199-205.

Toledo, J. B., Furlan, A. C., Pozza, P. C., Carraro, J., Moresco, G., Ferreira, S. L. \&Gallego, A. G. (2014). Reduction of the crude protein content of diets supplemented with essential amino acids for piglets weighing 15 to 30 kilograms. R. Bras. Zootec. 43, 301-309.

Zuidhof, M. (2019). A Review of Dietary Metabolizable and Net Energy: Uncoupling Heat Production and Retained Energy. J. Appl. Poult. Res. 28(2), 231241 .

Wang, Y., Zhou, J., Wang, G., Cai, S., Zeng, X., \& Qiao, S. (2018). Advances in low-protein diets for swine. J. Anim. Sci. Technol. 9, 1-14.

Wolp, R. C., Rodrigues, N. E. B., Zangeronimo, M. G., Cantarelli, V. S., Fialho, E. T., Philomeno, R., Alvarenga, R. R., \& Roch, L. F. (2012). Soybean oil and crude protein levels for growing pigs kept under heat stress conditions. Livest. Sci. 147, 148-153.

Xin, H., \& Harmon, J. D. (1998). Livestock Industry facilities and environment: heat stress indices for livestock agriculture and environment extension publications. 163. http://lib.dr.iastate.edu/extension_ag_pubs/163. 